and zoological subjects. The standard of the articles appears to be high, and the journal itself is well produced. A whole section of this issue of the Bulletin reports the proceedings of the Israel Chemical Society by giving adequate abstracts of the communications in inorganic, organic and physical chemistry which were delivered. There is also a biographical sketch of Prof. Andor Fodor, on the occasion of his seventieth birthday, to commemorate his long association with the Hebrew University and with the development of scientific work in Israel.

\section{Research Essay Competition}

THE Scientific Advisory Board of Research has decided for the third successive year to organize a "Science in Industry" essay competition. The purpose of the competition is to encourage scientists to take greater interest in the problem of presenting the results of scientific research work to people less highly qualified than themselves. It will be in two parts. The first part aims at directing attention to the problem of the scientist in communicating with the industrial policy-maker. Often, the board of directors of an industrial firm contains no member with scientific or technical training. Scientists must learn how to put forward the case for the development or investigation of some new scientific process or project in terms which a technically unqualified board can appreciate. Competitors are required to make their case in an essay of about three thousand words in length. Prizes amounting to $£ 200$ are to be awarded for this part of the competition. In addition, the author of the best essay will receive a special new award to be known as the Waverley Gold Medal. The second part of the competition requires the scientist to discuss one of four set subjects in a manner suitable for publication in a general newspaper. The prizes for this part of the competition, amounting to $£ 150$, are to be awarded by the Sunday Times. Further information can be obtained from the offices of Research, 88 Kingsway, London, W.C.2.

\section{Endeavour}

Maintaining its standard of excellence, the latest number of the journal Endeavour (issued by Imperial Chemical Industries, Ltd.) contains some interesting and important articles. Sir Macfarlane Burnet, for example, examines the riddle of the influenza virus and shows that growing knowledge of the influenza virus leads to the conclusion that, while this has distinct antigenic, enzymic and genetic properties, it is at the same time chemically indistinguishable from fragments of the cytoplasm of the cells in which it is a parasite; this conclusion is of fundamental importance, not only in devising new methods of attacking what can be a very deadly disease but also for understanding the structure and function of the vertebrate cell. Dr. Charles Singer describes some of Robert Hooke's brilliant contributions to biology, and Dr. E. N. Willmer discusses the sensation which human beings call "white". "Storms in the Ionosphere" is the subject of an article by Sir Edward Appleton, while the place of James Muspratt and his family in the British hesvy chemical industry is considered by Dr. D. W. F. Hardie. Dr. A. FreyWyssling describes some information collected by the use of the electron microscope in plant cytology, and Prof. Munro Fox surveys the principal types of coloration in animals and is supported by some colour photographs which have been faultlessly reproduced.

\section{Research in the Social Sciences}

THE National Institute of Economic and Social Research has again published its Register of Research in the Social Sciences. This follows the plan of the ten previous numbers, although two substantial changes have been made. The first has been to cut down drastically the amount of repetition of information that has already been recorded in previous issues. This will mean that, for fuller information about research items that have already been reported in a previous Register, the user must consult that issue; the reference back is given in each case. New information about work in progress or work newly completed has been included. The second change has been to revise the section of the classification dealing with economics. The new classification replaces one that had become progressively less suitable as a means of classifying contemporary research in Great Britain. The year 1953-54 shows a substantial increase in the number of new research projects that have been reported, the total having risen from 201 in $1952-53$ to 291 in the current Register. This increase is largely the consequence of the impact of the Conditional Aid economic and social research programmes in Great Britain. These new programmes, supported by funds derived from the United States, have provided finance for about sixty of the new inquiries reported here. The programmes are designed to encourage and expand research of all kinds into factors affecting the efficiency of the national economy. Thus nearly half the economic research recorded here into business structure and functioning, monopoly and competition, productivity and efficiency, is supported by Conditional Aid; it also provides funds for a quarter of the work in industrial relations and management.

\section{City of Manchester Public Libraries : Report for the Year 1953-54}

THE hundred and second report of the City of Manchester Public Libraries Committee (pp. $16+$ $28+35+4$ plates; Manchester Public Libraries, 1954) covers the year ended March 31,1954 , but records the death of the City Librarian, Mr. Charles Nowell, on August 9, 1954, while the report was in preparation. Although the reference libraries continued to attract more readers-627,847 in place of 602,528 the previous year, with an increase in the issue of books from 719,361 to 769,917 - fewer books were borrowed from the lending libraries, and the total number of volumes issued to readers decreased from $6,241,375$ to $5,929,621$. The addition of 102,115 volumes brought the total stock to $1,095,333$, of which 663,074 are available for loan. A census of users of the central library during 9 a.m.-9 p.m. was made on March 30, 1954, and the results are detailed in a summary accompanying, like the usual statistical summary, the annual report. Of 4,156 entering the library, 3,080 completed the census form as requested: of 689 users of the reference library, 237 lived in Manchester and 452 elsewhere; in the commercial library there were 192 Manchester residents to 305 outside the City boundary; in the technical library the proportion was 123 to 170 ; and in the central lending library, as might be expected, there were 816 Manchester residents to 314 non-residents. Of those visiting the periodicals room, 143 were Manchester residents and 120 from outside the City boundary; for the Henry Watson music library the 